\title{
ECONOMIC DEVELOPMENT AND ENVIRONMENT IN THE LIGHT OF INDIAN ENVIRONMENTAL JURISPRUDENCE
}

\section{Ms. Pandya Foram Amrishbhai}

\author{
\&
}

\section{Dr. Bhavesh H. Bharad}

\begin{abstract}
:
The conflict between economic growth and environment is sharper today than ever before, particularly in developing countries like India. India, just like other developing countries, has adopted development strategy based primarily on large-scale industrialization, energy-intensive technologies and biochemical-based agricultural technology which has led to environmental degradation.
\end{abstract}

The legislative and executive efforts have been notable towards Environmental Protection laws and principles in the legal jurisprudence of India, most notably the $46^{\text {th }}$ Amendment to the Constitution of India in 1976 which explicitly laid down Environmental Protection as part of the Constitution and enactment of the Environment Protection Act 1986. Though initiatives have been taken by the Legislature and the Executive, the Judiciary has taken a lead in this race through careful judicial thinking of the Courts which has been very helpful in controlling environmental pollution. Due to non-compliance of its own laws by the State machinery, the Judiciary invented a new method of Judiciary-driven implementation of the regulations in India. Recently judicial activism has provided impetus to campaign against various environmental pollution issues arising in the country. The Indian Judiciary has interpreted Art.21 to give it an expanded meaning to bring within its ambit the right of every citizen to a clean, safe and healthy environment.

The author in the current paper aims to analyze how far judicial activism has been effective in bringing about improvement in the environment and also aims to show how sustainable 
development is important to secure long term economic development in the country and make the economy resilient to future contingencies.

Key words: Environment, economic development, growth, population judicial activism, sustainable development.

\section{Introduction:}

In recent years there has been growing concern about degradation and pollution of environment and climate change as they impact on future development of both the developing and developed countries. In 1992, representatives of over 150 countries met at Rio in Brazil to discuss the environmental issues and their implications for future development of the world. This meeting at Rio is called the 'Earth summit' or the United Nations Conference on Environment and Development (UNCED).

This conference clearly spelled out the linkages between natural environment and development and put forward the concept of "sustainable development". This has produced greater awareness about environmental issues and facilitated the cooperation between different countries to reduce environmental degradation, particularly to reduce emission of greenhouse gases (GHG) such as carbon dioxide to prevent adverse climate change, that is, global warming in future which, if not prevented, will have disastrous consequences for the welfare and development of the population, both in developing and developed countries.

In recent years economists have increasingly become interested in environmental economics which is concerned with how economic activities of producers and consumers affect the environment in which we live and explain the policies to improve the quality of life of the present and future generation. Environmental issues are more important for developing countries where poverty prevails on a large scale and acceleration of economic growth is urgently needed.

The conflict between economic growth and environment is sharper today than ever before, particularly in developing countries like India with fast growing population and mass poverty. The developing countries are making strenuous efforts to balance their need for rapid economic growth with the environmental concerns for keeping their natural base intact. In India, as in other developing countries, the adoption of development strategy based primarily on large-scale 
industrialization, energy-intensive technologies and biochemical-based agricultural technology, which ignored indigenous development paradigm based on locally self-sufficient technologies, has led to environmental degradation.

In a conference of State Environment Ministers held in August 2009, Prime Minister Manmohan Singh said that the ecological crisis that confronts the country has led to 'alarming situation'. He urged upon the State governments to control environment pollution, clean rivers and fight climate change. This statement highlights the fact that India's growth is increasingly taking place at the cost of its environment. This shows that we have not been taking adequate measures to ensure sustainable development.

To stop further decline in our natural resources and protect environment from pollution stringent regulations and incentives are needed. But, as the PM has said, due to rampant corruption prevailing in the bureaucracy the rules regarding the use of our natural resources and protection of environment have been flouted with impunity. There are numerous instances when the Ministry of Environment and Forests has flouted all norms to give clearance to dubious projects at the cost of environment and communities that depend on it.

\section{International initiatives:}

The international community has taken many measures to protect, conserve and preserve the marine environment. The famous 'Stockholm Conference' was organized on 1972 and after that United Nations Conference on Environment and Development, popularly known as the 'RioEarth Summit', was held on 1992 at Rio de Janeiro. This Earth Summit of 1992 resulted in formation of Convention on Biological Diversity, 1992 along with other agreements on environment.

\section{Sustainable Development Goals 2030 or the 2030 Agenda:}

The Sustainable Development Goals (SDGs) or Global Goals for Sustainable Development are a collection of 17 global goals. They are formulated by the United Nations Development Programme.

The said goals cover various socio-economic development issues like global warming, poverty, hunger, health, education, sanitation, environment, energy, urbanization and social justice. 


\section{Environment and Human Rights:}

Human rights are rights which are inherent to all human beings right from his birth without any discrimination as to sex, race, nationality, ethnicity, language, religion, or any other criteria. Right to live in a safe, clean and healthy environment is a basic right of every human born on this planet.

In recent years the relationship between human rights and environmental issues has become a subject of lot of controversies and debate. A decent environment is a precondition for living a life of dignity and worth. International community has taken many measures to protect and preserve the environment for the present as well as the future generation by arranging many international conferences, conventions and treaties.

Millions of annual deaths and billions of cases of various chronic illnesses and diseases in today's times are attributed to various types of land,water and air pollution. All over the world people are experiencing the negative effects of environmental degradation and climate change. A clean and healthy environment is very essential to enjoy a physically and mentally healthy life and for all round development of human society. But due to the poor quality of environment and the natural resources men today is suffering from a lot of health, social and economic issues. There are three main components of the interrelationship between human rights and environmental protection:

- The environment as a pre-requisite for the enjoyment of human rights.

- Certain human rights, especially access to information, participation in decision-making, and access to justice in environmental matters, are essential to good environmental decision-making.

- The right to a safe, healthy and ecologically-balanced environment as a human right in itself. ${ }^{1}$

\footnotetext{
${ }^{1} \mathrm{UN}$ Environment,UNEP, available at http://web.unep.org/divisions/delc/human-rights-and-environment, visited on 20.10 .2018 at $12: 25 \mathrm{pm}$ 


\section{$\underline{\text { Indian law and environment: }}$}

\section{The Constitution of India:}

The Constitution of India when originally adopted did not contain any specific provisions regarding the protection of environment. May be, the framers of the Indian Constitution did not consider environment to be a crucial issue back then.

Article 21 of the Constitution of India talks about the right to life and personal liberty, it states that "No person shall be deprived of his life or personal liberty except according to procedure established by law." This article imposes a duty on the state to protect the life and liberty of the people. The Indian Judiciary while dealing with cases relating to environment considered the right to clean or the good environment as fundamental to life and upheld it as a fundamental right. The Judiciary has played a vital role in interpreting the Article 21 of the Indian Constitution. The scope of Article 21 of the Constitution has been considerably expanded by the Indian Supreme Court, which has interpreted the right of life to mean the right to live a civilized life and it also includes the right to clean environment. ${ }^{2}$ In India after the Stockholm Conference in 1976, under the $42^{\text {nd }}$ Amendment of the Constitution Article 48-A and Article 51-A (g) were inserted in the Indian Constitution. Article 48-A placed environment as responsibility of the state government under the Directive Principles of State Policy. Article 51-A (g) made environmental protection and conservation a Fundamental Duty of all the citizens of India.

\section{Landmark judgements:}

MC Mehta v. Union of India (Kanpur Tanneries case) ${ }^{3}$

Public interest litigation (P.I.L.) sought an order from the Supreme Court to restrain the tanneries near Kanpur city from discharging trade effluents into the river Ganga until they set up effluent treatment plants. Among other directions, the Court ordered stoppage of work in the tanneries, which were discharging effluents into the river and which did not set up primary treatment plants discharge of untreated wastewater into the river for several years.

\footnotetext{
${ }^{2}$ Lexpress, 'Right to clean and healthy environment' as a Fundamental Right in India, available at https://lexpress.in/environment/right-clean-healthy-environment-fundamental-right-india, visited on 21.10.2018 at 2:00pm

${ }^{3}$ M.C.Mehta v Union of India, AIR 1988 SC 1037(India)

Dec, 2018. VOL.10. ISSUE NO. 3

$\underline{\text { www.hrdcgujarat.ac.in }}$ 


\section{Indian Council for Enviro-Legal Action v Union of India and Others ${ }^{4}$}

In this particular case it was alleged that water in wells and streams in village Bichhri in Udaipur district in the State of Rajasthan had become unfit for consumption as a result of disposal of untreated toxic sludge from an industrial complex located within the limits of the village. The Supreme Court held that the respondents were absolutely liable to pay compensation for the harm caused by them to the villagers in the affected area and surrounding areas as well as to the environment.

\section{Vellore Citizens Welfare Forum v Union of India and Others ${ }^{5}$}

The petitioner organization was concerned about water pollution resulting from the discharge of untreated effluents by tanneries and other industries into river Palar in the State of Tamil Nadu, which was a source of drinking water supply. The Supreme Court directed the constitution of an authority under the Environment Act to deal with the situation created by the tanneries and other polluting industries in the State. The authority was also directed to frame and execute scheme(s) for reversing ecological/environmental damage caused by pollution in the State. It also imposed pollution fine on all the tanneries, and ordered the closure of tanneries that fail to pay the fine.

\section{Rural Litigation and Environment Kendra, Dehradun vs. State of Uttar Pradesh ${ }^{6}$}

In this particular case, before The Supreme Court of India, the representatives of the Rural Litigation and Entitlement Kendra, Dehradun wrote to the Supreme Court that the illegal limestone mining in the Mussorie-Dehradun region was causing damage to environment in that particular region. The Court treated this letter as a public interest petition under Article 32 of the Constitution and after ordering an inquiry into the issue ordered the closure of a number of limestone quarries.

\section{M.C. Mehta vs. Union of India (Vehicular Pollution Case) ${ }^{7}$}

This case was regarding the severe pollution caused in Delhi due to vehicles. The Apex court in this case again confirmed the right to a healthy environment as a basic human right while stating that the right to clean air emanates from Art. 21 which talks about Right to life. This case served

\footnotetext{
${ }^{4}$ Indian Council for Enviro-Legal Action v Union of India and Others, AIR 1996 SC 1446(India)

${ }^{5}$ Vellore Citizens Welfare Forum v Union of India and Others, AIR 1996 SC 2715(India)

${ }^{6}$ Rural Litigation and Entitlement v. State of U.P. \& Ors, 1989 AIR 5941989 SCC Supl. (1) 537 JT 1988 (4) 710 1988 SCALE (2) 1574

${ }^{7}$ M.C. Mehta v. Union of India, 1991 SCR (1)866, 1991 SCC (2) 353 (India) 
as an important landmark judgment. There was a complete phasing out old commercial vehicles more than 5 years old as directed by the courts and also made supply of lead free petrol mandatory in the capital.

\section{Economy-Environment Linkages (Relations):}

Modern economics is not only concerned with financial matters but also with several unpriced services and resources which natural environment provides us. In environmental economics how economic activity and policy affect the environment in which we live and also how environment supports economic activities. It is of great importance to explain how the economy and environment are interlinked. The environment supports economic activity by man in four ways it provides life support, supplies natural resources for production and consumption, absorbs waste products and supplies amenity services. The economy works from inside the environmental system and its activities affect the environment and the latter also affects the economy.

The economy is a system consisting of producing firms, consumers and the market system where interaction between the producers and consumers takes place. The purpose of economy is to produce goods and services to satisfy consumer wants. For the production of goods and services, the economy uses made-made capital, labour and natural resources (such as coal, oil (petroleum and diesel), CNG gas), minerals and metals, etc. from environment.

There are two types of resources - renewable and non-renewable. The renewable resources such as forests and fisheries are those whose quantity can be increased when they are depleted. For example, when, there is deforestation by cutting trees, new trees can be planted to make up the deficiency. Similarly, new fisheries can be developed. On the other hand, the non-renewable resources are those whose exhaustion as a result of their use cannot be made up. Coal, iron ore, crude oil are examples of non-renewable resources as they cannot be produced by man. They are also called exhaustible resources.

It may be noted that resource inputs are transformed by the economy into outputs. For example, wood through a production process is converted into paper and crude oil is refined to produce petrol. 
How the economy is related to the environment is depicted in Fig.1. The environment in Fig.1 is represented by the whole big circle. Note that the environment means all natural resources such as land, ecosystem (i.e., flora and fauna), all mineral and metal deposits under the land surface, world's oceans and atmosphere and natural climate. The economy is shown inside the environment system in which it works. As in the economy the firms produce goods and services with the use of natural resources, man-made capital and labour to satisfy the consumption wants of the households. There are many relations between the environment and the economy.

First, by providing a biological, chemical and physical system that makes it possible for human beings to live, the environment system that includes the air and atmosphere, rivers, the fertility of the soil and biodiversity (i.e., various types of plant and animal life) on which life of households depends. They are essential and necessary for their existence. If there is any large reduction in these conditions provided by the environment system, there will be highly devastating effect on human life. This life-support function of the environment system is shown by the arrow towards the economy in the upper part of Fig. 1.

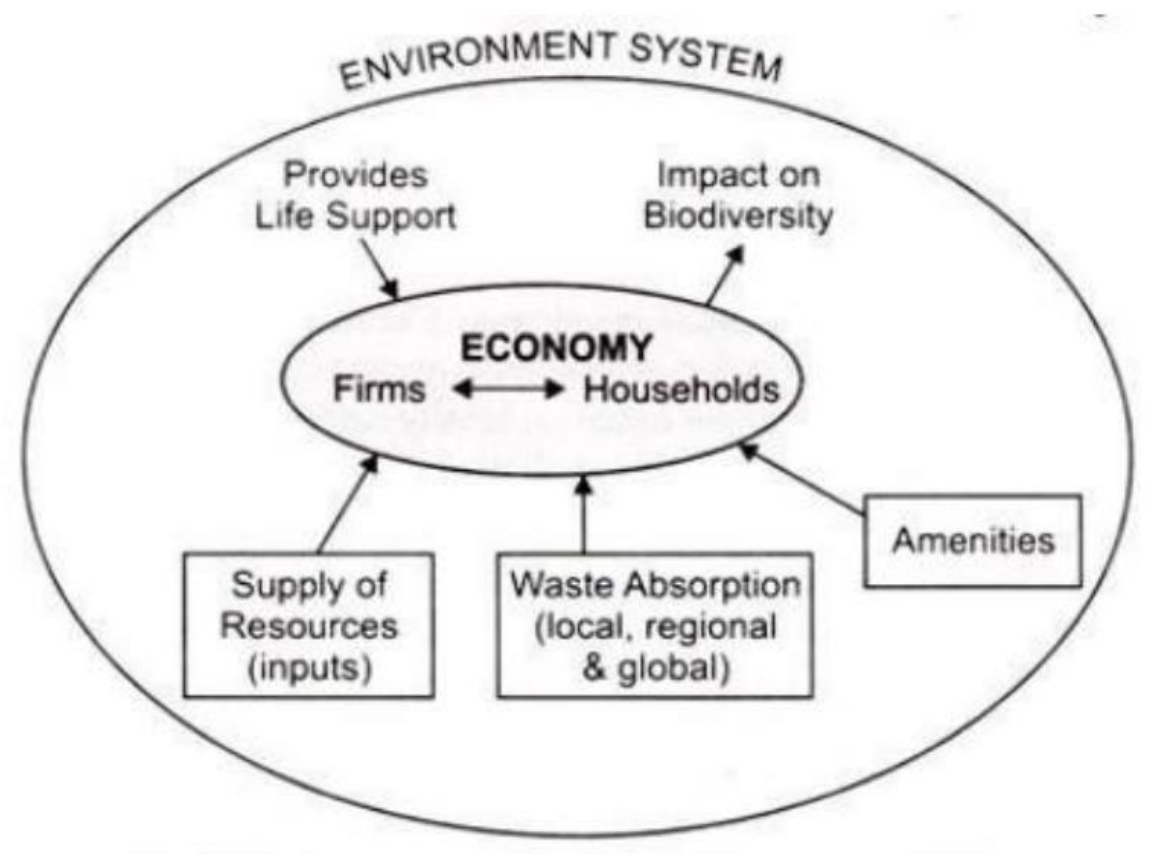

\section{Figure. 1}

Second, the environment provides raw materials and energy resources such as minerals, metals, food, wood and cotton for production and use by the firms and households in the economy. Dec, 2U18. VUL.1U. ISSUt NU. 3 
These natural resources may be renewable or non-renewable. Some non-renewable resources must be preserved for future generations and in this regard efforts should be made to find their man-made substitutes. For example, to save coal, solar energy can be used.

Besides, even renewable resources can be used in a sustainable manner. For example, to ensure deforestation should not result in desertification, new trees be planted to make up the loss of trees. The use of renewable resources is shown in Fig. 56.1 by the opposite flow of resources from the economy to the environment. As regards non-renewable resources such as coal and crude oil, their use causes permanent reduction in their stock.

Third important function of the environment is to absorb the waste products such as carbon dioxide $\left(\mathrm{CO}_{2}\right)$ which originate from the production processes of the firms, from power plants or the consumption activities of the households which generate garbage for collection and disposal. Thus, the environment is used as a waste sink. Wastes may be in a variety of basic forms such as solid, air and water-borne.

It is important to note that environment has a limited assimilative capacity to absorb these wastes or to dispose of them safely, that is, to transform them into some harmless substances. For example, carbon dioxide gas which is responsible for global warming is captured through growth of forests and a part is absorbed by oceans. Deforestation on a large scale and limited ability of oceans to absorb the carbon dioxide has caused the increase in global warming.

In this context, it is worth mentioning that the global warming in the Indian Ocean has disturbed the weather system in the Indian sub-continent and weakened monsoon in India on which a majority of farmers depend for their livelihood, Consequently, it has been suggested that to prevent the rise in global warming carbon dioxide emissions have to be reduced and alternative means of capturing these $\mathrm{CO}_{2}$ emission have to be followed. Besides, we need to take measures to adapt to climate change. Fourth, the environment provides the people with direct source of amenity services such as natural scenic beauty which give pleasure and happiness to them. The beauty of Kashmir Valley and of parts of Kerala of India is a source of greater happiness and therefore attracts a large number of tourists. These amenity services, though they are not essential for the existence of life, are a source of enjoyment, a sort of luxury for the people. 
It may be noted that different parts of the environment system may perform more than one function. For example, "the oceans are important in determining the life-support system provided by the global and microclimates; they are sources of many minerals and other resources; they assimilate many different wastes and they provide the space and opportunity for marine pastimes".

Further, the functions of environment may be competitive or complementary. For example, the excessive deposit of wastes in the oceans will reduce their capacity to provide habitat for fish stock. Environment functions may be complementary as the forestry policy of planting more trees can ensure sustainable way of reducing soil erosion (promoting a life support function), a source of timber (a function of natural resource supply) and absorbing carbon dioxide from the atmosphere (i.e., a waste absorption function).

From our above analysis, it is evident that the economy has important relations with the environment.

Economic development, especially industrialisation, is associated with the increase in consumption of energy which in the modern times is mostly derived from fossil fuels (petrol, diesel, coal). Before the modern industrial era, we used biomass for cooking and space heating and other economic activities were performed using muscle power of human labour and that of animals reared and domesticated by man for carrying out the various productive activities.

But the industrialisation along with rapid growth of population has necessitated the greater increase in consumption of energy which could no longer be adequately supplied by human and animal muscle power. As a result, to produce goods and services to meet the increasing consumption for them required the use of energy to be derived from fossil fuels. It is worth noting that even electricity is generated with the use of coal in thermal power plants or water in the hydel projects.

It is the energy derived from fossil fuels in the industrial development that creates external diseconomies in the form of pollution of air and water and involves the use of natural resources such as forests, minerals and water. Thus, rapid industrialisation in developed countries has resulted in the emission of large-scale carbon dioxide and other greenhouse gases which has Dec, 2018. VOL.10. ISSUE NO. 3 $\underline{\text { www.hrdcgujarat.ac.in }}$ Page | 68 
adversely affected our environment and created global warming with the disastrous consequences for the future generation.

Further, a key aspect of our economic development in the past is marked by total indifference to the use of key natural resources of the earth. This has led to unsustainable and inefficient increase in the growth of output of goods and services to meet the basic increases in consumption of the present generation at the cost of future generations. If this process of increases in consumption and growth continues, this will end in full exploitation of fossil fuels, the main source of energy today.

When this happens the process of economic development will cease and the economies will reach stagnation. Therefore, there is paramount need for use of renewable energy such as solar energy. To quote Mr. Pachauri again "the natural wealth of the planet and ability to use it for welfare is directly the gift of the sun, a reality that most of us seldom reflect on. We are living in a world where people believe that age of fossil fuels must inevitably come to a close and the future undeniably lies in the widespread use of renewable forms of energy".

In this context it is important to mention the theme of Rio-12 Earth Summit held in June 2012 at Rio which was to suggest measures to achieve the objective of green economy. A green economy is the one that results in improved human well-being and social equity while significantly reducing environmental risks and ecological scarcities. Growth in a green economy is driven by investments that reduce pressures on the environment and the services it provides us while enhancing the energy and resource efficiency. ${ }^{8}$

While developed countries which experienced unprecedented growth in the last more than a century there are several developing countries where a lot of population live in poverty and misery. It is the developed countries which have contributed most to the present level of environmental pollution and global warming. Therefore, they ought to help the poor developing countries with adequate funds and needed technology transfer and achieve sustainable development.

\footnotetext{
${ }^{8} \mathrm{UN}$ Chronicle, available at https://unchronicle.un.org/article/objectives-and-vision-rio20, visited on 22.10.2018 at $5: 13 \mathrm{pm}$ 


\section{Towards A Green India:}

- Although the past decade of rapid economic growth has brought many benefits to India, the environment has suffered, exposing the population serious air and water pollution.

- A new report finds that environmental degradation costs India $\$ 80$ billion per year or 5.7\% of its economy.

- Green growth strategies are needed promote sustainable growth and to break the pattern of environmental degradation and natural resource depletion. Emission reductions can be achieved with minimal cost to GDP.

Over the last decade, India's growth has increased employment opportunities and allowed millions to emerge from poverty.

India's remarkable growth record, however, has been clouded by a degrading environment and growing scarcity of natural resources. Mirroring the size and diversity of its economy, environmental risks are wide ranging and are driven by both prosperity and poverty.

In a recent survey of 178 countries whose environments were surveyed, India ranked 155th overall and almost last in air pollution exposure. ${ }^{9}$ The survey also concluded that India's environmental quality is far below all BRIC countries [China (118), Brazil (77), Russia (73), and South Africa (72)]. Also, according to another recent WHO survey, across the G-20 economies, 13 of the 20 most polluted cities are in India. Simultaneously, poverty remains both a cause and consequence of resource degradation: agricultural yields are lower on degraded lands, and forests and grasslands are depleted as livelihood resources decline. To subsist, the poor are compelled to mine and overuse the limited resources available to them, creating a downward spiral of impoverishment and environmental degradation.

But does growth - so essential for development - have to come at the price of worsened air quality and other environmental impacts?

\section{Conclusion and Findings:}

\footnotetext{
${ }^{9}$ The Times of India, available at https://timesofindia.indiatimes.com/home/environment/pollution/Indias-airquality-among-five-worst/articleshow/29572834.cms, visited on 23.10 .2018 at $5: 58 \mathrm{pm}$ 
First, Environmental sustainability could become the next major challenge as India surges along its projected growth trajectory

Second, a low-emission, resource-efficient greening of the economy should be possible at a very low cost in terms of GDP growth. While a more aggressive low-emission strategy comes at a slightly higher price tag for the economy it promises to deliver greater benefits.

Third, for an environmentally sustainable future, India needs to value its natural resources, and ecosystem services to better inform policy and decision-making.

\section{"While the overall policy focus should be on meeting basic needs and expanding opportunities for growth, they should not be at the expense of unsustainable environmental degradation."}

- Green growth is necessary- With cost of environmental degradation at approximate US $\$ 80$ billion annually, environment could become a major constraint in sustaining future economic growth. Further, it may be impossible or prohibitively expensive to clean up later.

- Green growth is affordable- Model simulations suggest that policy interventions such as environmental taxes could potentially be used to yield positive net environmental and health benefits with minimal economic costs for India.

- Green growth is desirable- For an environmentally sustainable future, India needs to value its natural resources, and ecosystem services to better inform policy and decision-making especially since India is a hotspot of unique biodiversity and ecosystems.

- Green growth is measurable- Conventional measures of growth do not adequately capture the environmental costs. Therefore, it is imperative to calculate green Gross Domestic Product (green GDP) as an index of economic growth with the environmental consequences factored in.

Thus, a low-emission, resource-efficient greening of the economy should be possible at a very low cost in terms of GDP growth. A more aggressive low-emission strategy comes at a slightly higher price tag for the economy while delivering greater benefits

Emissions reduction would have a minimal impact on GDP which would be offset by savings through improving health while substantially reducing carbon emissions. 
- A 10\% -30\% particulate emission reductions will lower GDP only modestly, but there will be significant health benefits which will compensate for the projected GDP loss.

- The savings from reduced health damages will also be a huge benefit to the developing economies.

- Under the scenarios, another important benefit would be a substantial reduction in $\mathrm{CO} 2$ as a co-benefit.

\author{
Ms. Foram Amrishbhai Pandya \\ Research Scholar, \\ University School of Law, Gujarat University, Ahmedabad \\ foram_1593@yahoo.com \\ $\boldsymbol{\&}$ \\ Dr. Bhavesh H. Bharad \\ Assistant Professor, \\ University School of Law, Gujarat University, Ahmedabad \\ dr.bharad@gmail.com
}

